\title{
Water-Level Changes in the High Plains Aquifer, Predevelopment to 2003 and 2002 to 2003
}

\author{
-By V.L. McGuire
}

The High Plains aquifer underlies one of the major agricultural regions in the world, including parts of eight states-Colorado, Kansas, Nebraska, New Mexico, Oklahoma, South Dakota, Texas, and Wyoming. In parts of the area that overlie the High Plains aquifer, farmers began extensive use of ground water for irrigation starting in the 1930's and 1940's. Estimated irrigated acreage in the area that overlies the High Plains aquifer increased rapidly from 1940 to 1980 , but did not change greatly from 1980 to 2002: 1949-2.1 million acres, 1980-13.7 million acres, 199713.9 million acres, 2002-12.7 million acres. However, the proportion of irrigated acreage in each state relative to total irrigated acres did change substantially over time in some states: 1980-21 percent of irrigated acres were in Kansas, and 38 percent of irrigated acres were in Nebraska; 2002-15 percent of irrigated acres were in Kansas, and 45 percent of irrigated acres were in Nebraska (Heimes and Luckey, 1982; Thelin and Heimes, 1987; U.S. Department of Agriculture, 1999, 2004). Annual ground-water withdrawals from the High Plains aquifer for irrigation, which is compiled by the U.S. Geological Survey and agencies in each State about every 5 years, increased from 4 to 19 million acre-feet from 1949 to 1974; ground-water withdrawals for irrigation decreased from 1974 to 1995 and increased from 1995 to 2000 (Heimes and Luckey, 1982; U.S. Geological Survey, 2004; U.S. Geological Survey's National WaterData Storage and Retrieval System database). Ground-water withdrawals for irrigation in 1980, 1985, 1990, and 1995 were from 4 to 18 percent less than withdrawals for irrigation in 1974. Ground-water withdrawals for irrigation in 2000 were 12 percent greater than withdrawals in 1995 and 2 percent greater than withdrawals in 1974. Ground-water withdrawals for irrigation during 2000 by county in the area that overlies the High Plains aquifer ranged from zero to

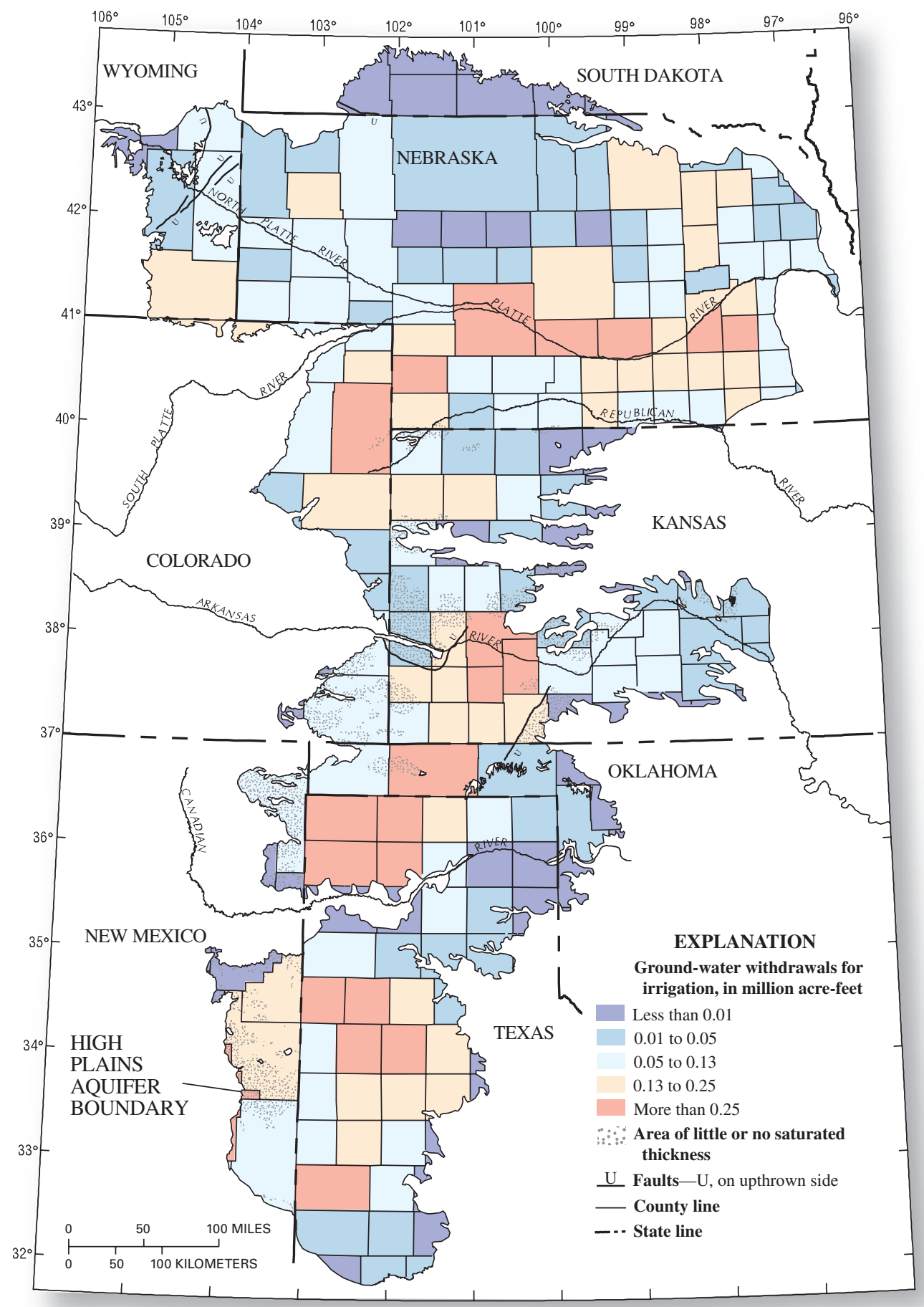

Base from U.S. Geological Survey digital data, 1:2,000,000 Albers Equal-Area projection, Horizontal datum NAD83,

Standard parallels $29^{\circ} 30^{\prime}$ and $45^{\circ} 30^{\prime}$, central meridian $-101^{\circ}$

Figure 1. Ground-water withdrawals for irrigation by county during 2000 (U.S. Geological Survey, 2004). 
0.5 million acre-feet (fig. 1); more than 96 percent of the total withdrawals from the aquifer were for irrigation (U.S. Geological Survey, 2004; Joan Kenny, U.S. Geological Survey, written commun., March 2004).

Water-level declines started to occur in the High Plains aquifer soon after the beginning of extensive ground-water irrigation. The water-level changes in the High Plains aquifer result from an imbalance between discharge and recharge. Discharge is primarily from ground-water withdrawals for irrigation, but also includes evapotranspiration, where the water table is near land surface, and seepage to streams and springs where the water table intersects the land surface. Recharge is primarily from precipitation; other sources of recharge are irrigation return flow and seepage from streams, canals, and reservoirs. By 1980, water levels in the High Plains aquifer in parts of Texas, Oklahoma, and southwestern Kansas had declined more than 100 feet (Luckey and others, 1981). Water-level declines may result in increased costs for ground-water withdrawals because of increased pumping lift and decreased well yields. Water-level declines also can affect ground-water availability, surface-water flow, and nearstream habitat (riparian) areas.

In response to the water-level declines in the High Plains aquifer, the U.S. Geological Survey, in cooperation with numerous Federal, State, and local water-resource agencies, began monitoring more than 7,000 wells in 1988 to assess the annual waterlevel change in the aquifer; there were 9,202 wells measured for 2003 (table 1). The purpose of this report is to present water-level changes in the High Plains aquifer from the time prior to substantial ground-water irrigation development (about 1950, which is termed "predevelopment" in this report) to 2003 and from 2002 to 2003 . The water-level measurements used in this report generally were collected in winter or early spring, when irrigation wells typically were not pumping and water levels generally had

Table 1. Number of wells used in this report for 2003 water levels and number of wells used for the water-level comparison periods, predevelopment to 2003 and 2002 to 2003.

\begin{tabular}{lccc}
\hline & & $\begin{array}{c}\text { Wells used in water- } \\
\text { level comparison } \\
\text { periods }\end{array}$ \\
\cline { 2 - 4 } State & $\mathbf{2 0 0 3}$ & $\begin{array}{c}\text { Predevelop- } \\
\text { ment to }\end{array}$ & $\mathbf{2 0 0 2 \text { to }}$ \\
\hline Colorado & $\mathbf{2 0 0 3}$ & $\mathbf{2 0 0 3}$ \\
Kansas & 1,424 & 333 & 455 \\
Nebraska & 3,776 & 606 & 1,313 \\
New Mexico & 154 & 204 & 3,506 \\
Oklahoma & 290 & 175 & 107 \\
South Dakota & 115 & 70 & 263 \\
Texas & 2,922 & 807 & 111 \\
Wyoming & 53 & 18 & 2,404 \\
\hline High Plains (Total) & 9,202 & 3,792 & 8,208 \\
\hline * Includes 1999 to 2002 water levels, instead of 2003 water levels, for \\
166 wells because many wells in New Mexico are measured on a \\
5-year schedule. & & & \\
& & & 49 \\
\hline
\end{tabular}

recovered from the stress of pumping during the previous irrigation season; an exception was that in 2003, most wells in South Dakota were measured in late spring or early summer.
The water-level-change maps and related area-weighted average water-level change values in this report were prepared using two methods. The map of water-level changes, predevelopment to 2003 (fig. 2), shows areas of water-level change ranges, which were determined manually based on predevelopment and 2003 water-level data from available wells and areas of water-level changes from previous reports (Lowry and others, 1967; Luckey and others, 1981; Nebraska Conservation and Survey Division, 2004). The map of generalized water-level changes, 2002 to 2003 (fig. 3), shows computer-generated Thiessen polygons (Thiessen, 1911), colored by the water-level-change range. Thiessen polygons apportion the water-level change in each well to an area around the well; the size of each polygon depends on the proximity of neighboring wells.

The predevelopment to 2003 area-weighted average waterlevel change (table 2) was computed by summing the quantity equal to the area within each polygon of water-level change

Table 2. Area-weighted average water-level changes in the High Plains aquifer, not including the areas of little or no saturated thickness, predevelopment to 2003 and 2002 to 2003.

\begin{tabular}{lcc}
\hline & \multicolumn{2}{c}{$\begin{array}{c}\text { Area-weighted } \\
\text { average water- } \\
\text { level change }\end{array}$} \\
\cline { 2 - 3 } \multicolumn{1}{c}{ State } & $\begin{array}{c}\text { Predevelopment } \\
\text { to 2003 } \\
\text { (feet) }\end{array}$ & $\begin{array}{c}\mathbf{2 0 0 2} \text { to } \\
\mathbf{2 0 0 3} \\
\text { (feet) }\end{array}$ \\
\hline Colorado & -9.9 & -1.0 \\
Kansas & -18.9 & -1.7 \\
Nebraska & -0.3 & -1.3 \\
New Mexico & -14.4 & -0.6 \\
Oklahoma & -13.7 & -0.8 \\
South Dakota & 0.2 & -0.8 \\
Texas & -34.9 & -1.2 \\
Wyoming & -0.2 & -0.3 \\
\hline High Plains (Total) & -12.6 & -1.2 \\
\hline
\end{tabular}

multiplied by the value of the mid-point of the polygon range and by dividing the result by the total area. The 2002 to 2003 areaweighted average water-level change was computed by summing the quantity equal to the area of each Thiessen polygon multiplied by the actual water-level change value associated with the Thiessen polygon and by dividing the result by the total area.

\section{WATER-LEVEL CHANGES, PREDEVELOPMENT TO 2003}

The map of water-level changes in the High Plains aquifer from predevelopment to 2003 (fig. 2) is based on water levels from 3,792 wells (table 1). The water-level changes from predevelopment to 2003 ranged between a rise of 86 feet and a decline of 223 feet. The area-weighted average water-level change across the High Plains, not including the areas with little or no saturated thickness, was a decline of 12.6 feet (table 2). Approximately 24 percent of the aquifer area, not including the areas with little or no saturated thickness, had more than 10 feet of water-level decline from predevelopment to $2003 ; 17$ percent had more than 


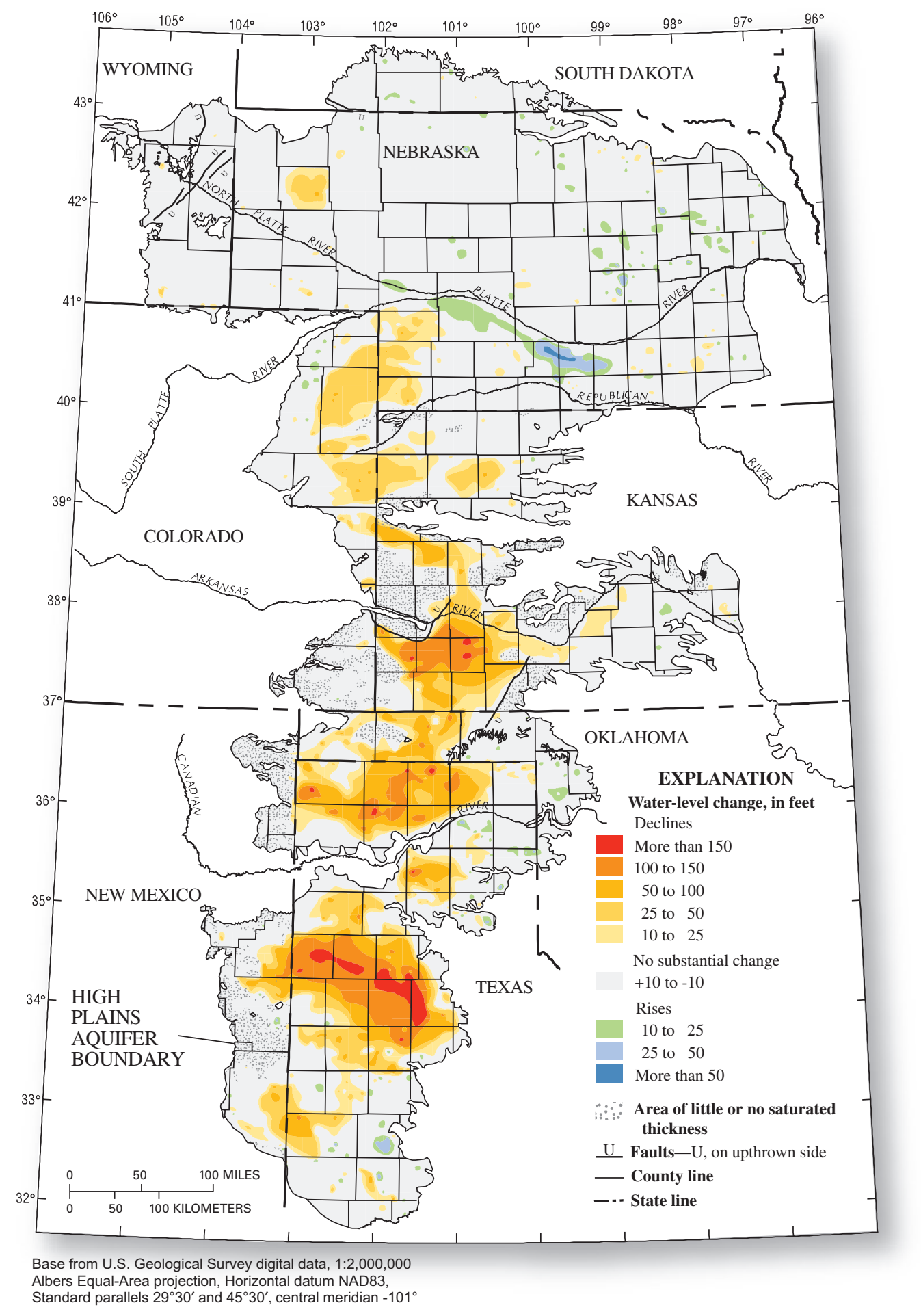

Figure 2. Water-level changes in the High Plains aquifer, predevelopment to 2003 (Modified from Lowry and others, 1967; Luckey and others, 1981; Nebraska Conservation and Survey Division, 2004).

25 feet of water-level decline, and 9 percent had more that 50 feet of water-level decline. The largest areas with greater than 50 feet of water-level decline occurred in southwest Kansas, east-central New Mexico, the central part of the Oklahoma Panhandle, and the western part of the Texas Panhandle.

\section{WATER-LEVEL CHANGES, 2002 T0 2003}

Water-level changes in the 8,208 wells used for the 2002 to 2003 comparison period (table 1) ranged between a rise of 9 feet and a decline of 14 feet; water-level declines of 3 feet or greater occurred in 19 percent of the wells measured (fig. 3). The areaweighted average water-level change in the High Plains aquifer 


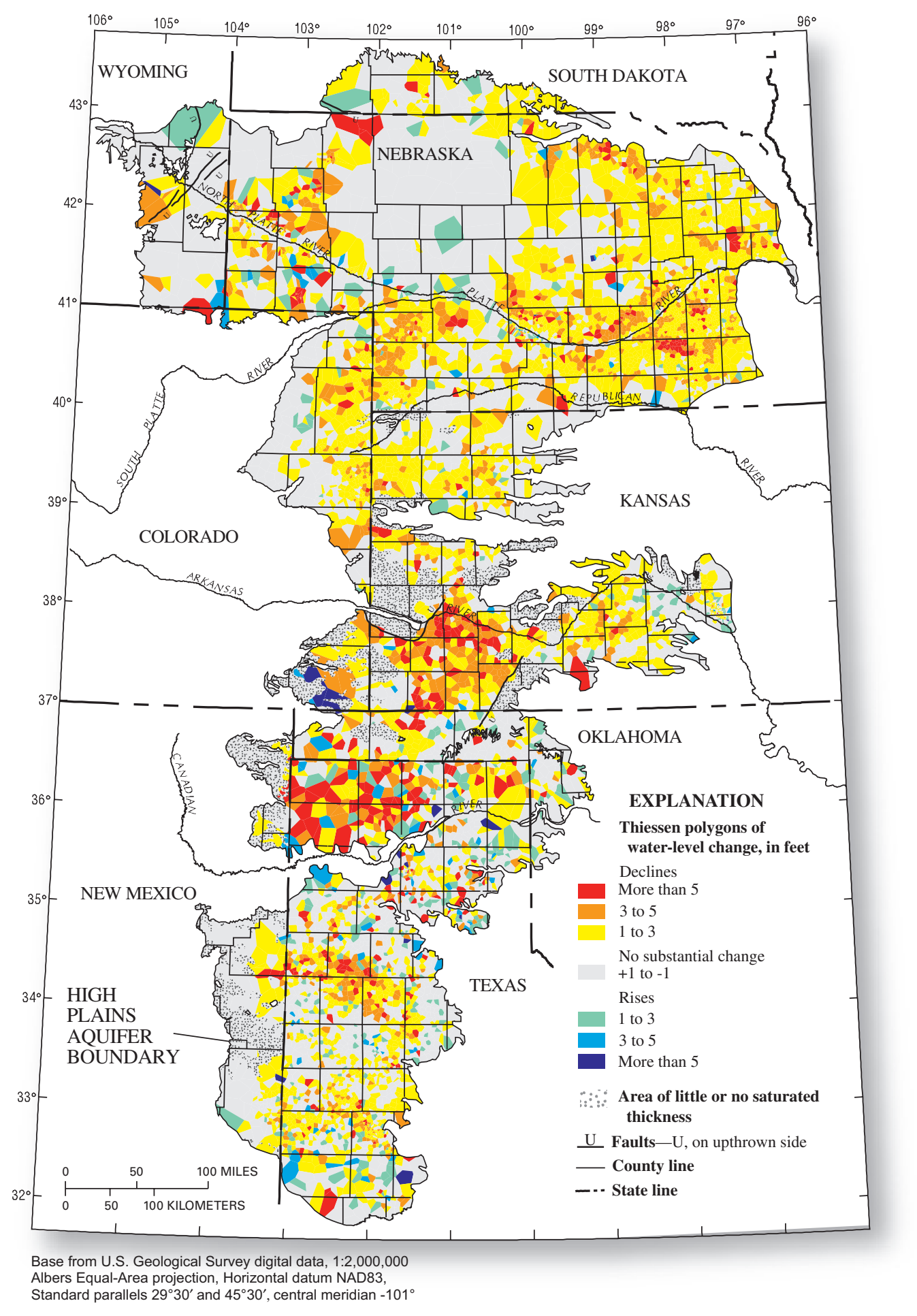

Figure 3. Generalized water-level changes in the High Plains aquifer, 2002 to 2003.

from 2002 to 2003, not including the areas of little or no saturated thickness, ranged by State from a decline of 1.7 feet in Kansas to a decline of 0.3 foot in Wyoming (table 2). The area-weighted average water-level change in the High Plains aquifer from 2002 to 2003 for the aquifer area, not including the areas of little or no saturated thickness, was a decline of 1.2 feet (table 2).

\section{CHANGE IN WATER IN STORAGE, PRE- DEVELOPMENT TO 2003}

Because the High Plains aquifer is generally unconfined, the change in water in storage in the High Plains aquifer can be estimated using the water-level change maps (figs. 2 and 3) and the average specific yield of the aquifer (Gutentag and others, 1984). Specific yield is an estimate of the volume of water that a volume of the aquifer will yield by gravity drainage (Lohman, 1979). 
This method for calculating the change in water in storage will overestimate the change in storage in local areas if the aquifer was under confined conditions at the start of the time period and unconfined conditions later.

Total water in storage in 2003 was about 2,940 million acre-feet, which was a decline of about 235 million acre-feet since predevelopment (fig. 4); total water in storage in 2003 was estimated from total water in storage in 2000, which was based on the saturated thickness of the aquifer in 2000 (McGuire and others, 2003), and the sum of annual changes in water in storage from 2000 to 2003, which was based on average area-weighted water-level changes calculated from Theissen polygons (McGuire, 2003, 2004; table 3). Total water in storage in predevelopment was inferred from total water in storage in 2000 and water-level changes, predevelopment to 2000 (McGuire and others, 2003). There were changes in storage prior to "predevelopment," as defined in this report, but this change in storage was not calculated here. Water in storage declined about 150 million acre-feet from predevelopment to 1980 based on predevelopment and 1980 water levels (Luckey and others, 1981; McGuire, 2004); the annual change in storage from predevelopment to 1980 and from 1981 to 1987 were not calculated for this report. For this report, total ground water in storage from 1988 to 2000 (fig. 4) was calculated by subtracting annual changes in water in storage, 1988 to 2000, from total water in storage in 2000 (Dugan and Cox, 1994; Dugan and others, 1990, 1994; Dugan and Schild, 1992; Dugan and Sharpe, 1996; Kastner and others, 1989; McGrath and Dugan, 1993; McGuire, 2001, 2003; McGuire and Fischer, 1999, 2000; McGuire and others, 1999, 2003; McGuire and Sharpe, 1997). The sum of annual changes in water in storage from 1988 to 2000 was a decline of about 47 million acrefeet, based on average area-weighted water-level changes calculated from Thiessen polygons.

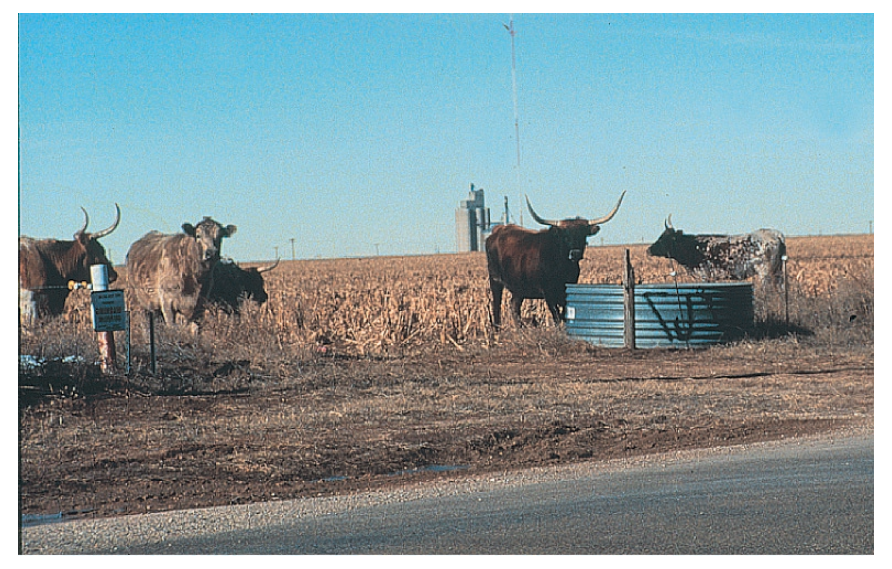

Cattle grazing in Cimarron County, Oklahoma (Photograph courtesy of R.R. Luckey, U.S. Geological Survey).

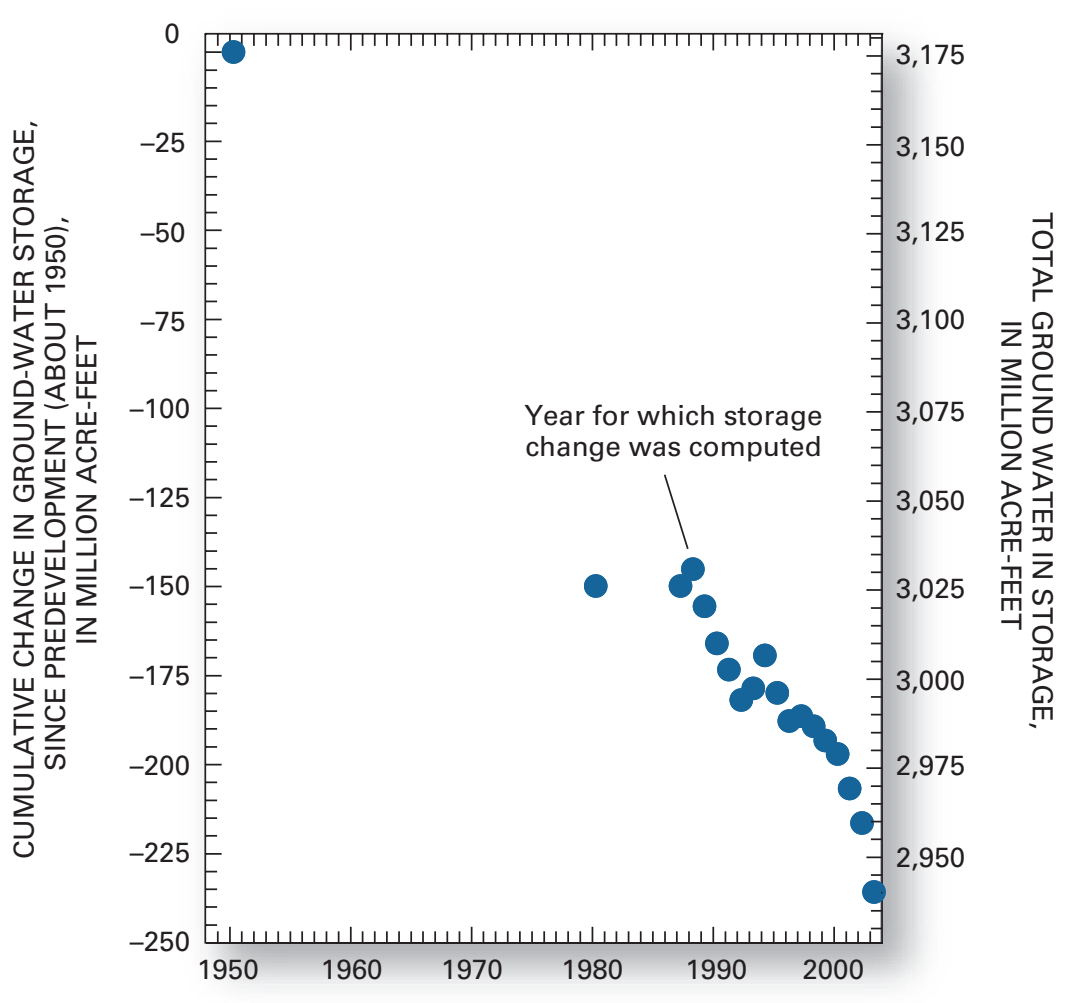

Figure 4. Cumulative change and total ground-water in storage in the High Plains aquifer for selected years, predevelopment through 2003 (Modified from McGuire and others, 2003; McGuire, 2004).
Table 3. Change in water in storage in the High Plains aquifer, predevelopment to 2003 and 2002 to 2003.

\begin{tabular}{lcc}
\hline & \multicolumn{2}{c}{ Change in water in storage } \\
\cline { 2 - 3 } \multicolumn{1}{c}{ State } & $\begin{array}{c}\text { Predevelop- } \\
\text { ment to 2003 } \\
\text { (million acre- } \\
\text { feet) }\end{array}$ & $\begin{array}{c}\text { 2002 to 2003 } \\
\text { (million } \\
\text { acre-feet) }\end{array}$ \\
\hline Colorado & -13.9 & -1.1 \\
Kansas & -55.6 & -4.1 \\
Nebraska & -11.4 & -8.1 \\
New Mexico & -9.0 & -0.3 \\
Oklahoma & -11.4 & -0.5 \\
South Dakota & -0.4 & -0.4 \\
Texas & -133.0 & -4.2 \\
Wyoming & -0.5 & -0.2 \\
\hline High Plains (Total) & -235.2 & -18.9 \\
\hline
\end{tabular}




\section{REFERENCES}

Dugan, J.T., and Cox, D.A., 1994, Water-level changes in the High Plains aquifer-Predevelopment to 1993: U.S. Geological Survey Water-Resources Investigations Report 94-4157, 60 p.

Dugan, J.T., McGrath, T.S., and Zelt, R.B., 1994, Water-level changes in the High Plains aquifer-Predevelopment to 1992: U.S. Geological Survey Water-Resources Investigations Report 94-4027, 56 p.

Dugan, J.T., and Schild, D.E., 1992, Water-level changes in the High Plains aquifer-Predevelopment to 1990: U.S. Geological Survey Water-Resources Investigations Report 91-4165, 55 p.

Dugan, J.T., Schild, D.E., and Kastner, W.M., 1990, Water-level changes in the High Plains aquifer underlying parts of South Dakota, Wyoming, Nebraska, Colorado, Kansas, New Mexico, Oklahoma, and Texas-Predevelopment through nonirrigation season 1988-89: U.S. Geological Survey Water-Resources Investigations Report 90-4153, $29 \mathrm{p}$.

Dugan, J.T., and Sharpe, J.B., 1996, Water-level changes in the High Plains aquifer-Predevelopment to 1994: U.S. Geological Survey Water-Resources Investigations Report 95-4208, 1 sheet.

Gutentag, E.D., Heimes, F.J., Krothe, N.C., Luckey, R.R., and Weeks, J.B., 1984, Geohydrology of the High Plains aquifer in parts of Colorado, Kansas, Nebraska, New Mexico, Oklahoma, South Dakota, Texas, and Wyoming: U.S. Geological Survey Professional Paper 1400-B, 63 p.

Heimes, F.J., and Luckey, R.R., 1982, Method for estimating irrigation requirements from ground water in the High Plains in parts of Colorado, Kansas, Nebraska, New Mexico, Oklahoma, South Dakota, Texas, and Wyoming: U.S. Geological Survey Water-Resources Investigations Report 82-40, 64 p.

Kastner, W.M., Schild, D.E., and Spahr, D.S., 1989, Water-level changes in the High Plains Aquifer underlying parts of South Dakota, Wyoming, Nebraska, Colorado, Kansas, New Mexico, Oklahoma, and Texas-predevelopment through nonirrigation season 1987-88: U.S. Geological Survey Water-Resources Investigations Report 89-4073, $61 \mathrm{p}$.

Lohman, S.W., 1979, Ground-water hydraulics: U.S. Geological Survey Professional Paper 708, 70 p.

Lowry, M.E., Crist, M.A., and Tilstra, J.R.,1967, Geology and groundwater resources of Laramie County, Wyoming; with a section on chemical quality of ground water and of surface water: U.S. Geological Survey Water-Supply Paper 1834, 71 p.

Luckey, R.R., Gutentag, E.D., and Weeks, J.B., 1981, Water-level and saturated-thickness changes, predevelopment to 1980, in the High Plains aquifer in parts of Colorado, Kansas, Nebraska, New Mexico, Oklahoma, South Dakota, Texas, and Wyoming: U.S. Geological Survey Hydrologic Investigations Atlas HA-652, 2 sheets, scale $1: 2,500,000$.

McGrath, T., and Dugan, J.T., 1993, Water-level changes in the High Plains Aquifer-predevelopment to 1991: U.S. Geological Survey Water-Resources Investigations Report 93-4088, 53 p.

McGuire, V.L., 2001, Water-level changes in the High Plains Aquifer, 1980-1999: U.S. Geological Survey Fact Sheet FS-0029-01, 2 p.

McGuire, V.L., 2003, Water-level changes in the High Plains aquifer, predevelopment to 2001, 1999 to 2000, and 2000 to 2001: U.S. Geological Survey Fact Sheet FS-078-03, 4 p.
McGuire, V.L., 2004, Water-level changes in the High Plains aquifer, predevelopment to 2002, 1980 to 2002, and 2001 to 2002: U.S. Geological Survey Fact Sheet FS-2004-3026, 6 p.

McGuire, V.L., and Fischer, B.C., 2000, Water-level changes in the High Plains, 1980 to 1998: U.S. Geological Survey, accessed August 26, 2004 at URL http://www-ne.cr.usgs.gov/highplains/hp98_ web_report/hp98fs.htm.

McGuire, V.L., and Fischer, B.C., 1999, Water-level changes, 1980 to 1997, and saturated thickness 1996-97, in the High Plains Aquifer: U.S. Geological Survey Fact Sheet FS-124-99, 4 p.

McGuire, V.L., Johnson, M.R., Schieffer, R.L., Stanton, J.S., Sebree, S.K., and Verstraeten, I.M., 2003, Water in storage and approaches to ground-water management, High Plains aquifer, 2000: U.S. Geological Survey Circular 1243, 51 p.

McGuire, V.L., and Sharpe, J.B., 1997, Water-level changes in the High Plains Aquifer, 1980 to 1995: U.S. Geological Survey Fact Sheet FS-0068-97, 4 p.

McGuire, V.L., Stanton, C.P. and Fischer, B.C., 1999, Water-level changes in the High Plains aquifer-1980 to 1996: U.S. Geological Survey, accessed August 26, 2004, at URL http://ne.water.usgs.gov/ html/highplains/hp96_web_report/hp96_factsheet.htm.

Nebraska Conservation and Survey Division, 2004, Groundwater-level changes in Nebraska from predevelopment to spring 2003: University of Nebraska-Lincoln data, accessed July 11, 2004 at URL http://csd.unl.edu/csd-esic/gisdata/pred03z14.e00.

Thiessen, A.H., 1911, Precipitation averages for large areas: Monthly Weather Review, v. 39, p. 1082-1084.

Thelin, G.P., and Heimes, F.J., 1987, Mapping irrigated cropland from Landsat data for determination of water use from the High Plains aquifer in parts of Colorado, Kansas, Nebraska, New Mexico, Oklahoma, South Dakota, Texas, and Wyoming: U.S. Geological Survey Professional Paper 1400-C, 38 p.

U.S. Department of Agriculture, 1999, 1997 Census of agriculture geographic area series: National Agricultural Statistics Service CD-ROM AC97-CD-VOL1-1B.

U.S. Department of Agriculture, 2004, Census of agriculture, volume 1, County level data: National Agriculture Statistics Service, accessed July 13, 2004 at URL http://www.nass.usda.gov/census/census02/ volume1/index $2 . h$ tm.

U.S. Geological Survey, 2004, Water Use in the United States: U.S. Geological Survey data, accessed July 29, 2004 at URL http://water.usgs.gov/watuse/.

For additional information contact:

U.S. Geological Survey

Federal Bldg., Room 406

100 Centennial Mall North

Lincoln, NE 68508

(402) 437-5082

USGS Nebraska District home page:

http://ne.water.usgs.gov 